\title{
The role of powered support in ensuring the proper longwall working cross-section area in rockburst-prone seams
}

\author{
Zbigniew Lubosik, Sylwester Rajwa, Andrzej Walentek, Wojciech Masny ${ }^{*}$, and Aleksander \\ Wrana \\ Główny Instytut Górnictwa , Department of Extraction Technology, Rockburst and Mining Support, \\ Plac Gwarków 1, Katowice, Poland
}

\begin{abstract}
In Poland, for underground hard coal seam extraction, the longwall method is used. Retreat longwalls with natural roof caving in the gob are the most common. Currently it is estimated that about a half of the hard coal output in Poland originates from seams located in areas of rock burst hazard. The article shows information about 18 rock bursts, and 14 other seismic events which occurred between 2003 and 2012 in underground mines belonging to one of coal companies in Poland. In addition, negative consequences of those dynamic phenomena in the longwall workings are described. In the next part of paper, the most common types of damage to powered supports after the rock mass tremors and other dynamic phenomena in longwall workings are shown. In order to avoid damage of powered supports, in geo-mining conditions where dynamic phenomena occur, different types of protective means are applied. In the paper the methodology of assessing the powered support yield ability is described. At the end, an example of the assessed yield ability of a powered support in given geo-mining conditions of a longwall face affected by the seismic events is presented.
\end{abstract}

\section{Introduction}

In Poland production of hard coal is conducted in increasingly harder geological and mining conditions, resulting from, among others, still growing depth of mining operations and numerous former exploitation in the mined longwall panels in form of edges and/or residues. The factors generally increase the level of natural hazard in Polish mines. One of them, a very important one, is rock burst hazard associated with occurrence of rock mass tremors. The hazard directly affects both personnel's safety and continuity of coal production.

Rock mass tremors induced by mining operations may result in rock bursts or decompressions. According to Polish regulations a rock burst is defined as a dynamic phenomenon caused by a rock mass tremor which results in destroying or damaging a working, or its fragment, leading to the complete or partial loss of its functionality or

\footnotetext{
Corresponding author: w.masny@gig.eu
} 
making it dangerous to use. While decompression is defined as a dynamic phenomenon caused by a rock mass tremor which causes damage to a mine working (or its fragment), yet does not result in loss of functionality nor renders it unsafe for personnel.

Rock bursts occur in six continents: Europe (Poland, Czech Republic, Germany, France and Slovenia), Asia (Russia, India, and China), North and South America (USA, Canada, and Chile), Africa (RSA) and Australia (New South Wales, Queensland and Western Australia). The first record of a rock burst was documented in Derbyshire lead mine in Great Britain in 1738. In the 19th century rock bursts also occurred in the Ruhr. The earliest record of a rock burst in Upper Silesian Coal Basin (GZW) comes from 1858 and concerns the occurrences in Fanny coal mine and Król coal mine in 1875 [1]. That is why the subject of influence of dynamic events on the underground workings has been researched and analyzed for over 200 years [2-16],

The consequences of dynamic events are severe threat to the crew working underground. It is not only caused by dynamic movement of roof, floor and sites of the galleries. The rapid reduction of the galleries cross-cut leads to the important disturbances in mines ventilation network. Moreover in gassy seams the destruction of rock mass can lead to uncontrolled release of methane to the mine air.

Hard coal mining operations, in areas where dynamic phenomena occur, requires considering both static and dynamic load while designing support both for headings and longwalls, as, when a tremor occurs, there is an increase in the value of load exerted on a support, and the main task of a properly designed support ought to be maintaining stability of a mine working and providing proper level of safety for the personnel.

\section{General characteristics of hard coal mining in Poland}

The hard coal deposits in Poland are mined in two coal basins, namely Lublin Coal Basin (LZW) and Upper Silesian Coal Basin (GZW). Lublin Coal Basin is located in southeastern part of Poland, near the border with Ukraine. At the moment one coal mine - LW Bogdanka, operates there. Upper Silesian Coal Basin is located in the south of Poland near an urban agglomeration, with Katowice in its centre. Mining operations in Upper Silesian Coal Basin have been conducted for over 200 years.

Between 2003 and 2014 hard coal mining operations in Upper Silesian Coal Basin resulted in approximately 14,000 tremors of seismic energy $E \geq 10^{5}$ (local magnitude, $\mathrm{M}_{\mathrm{L}} \geq 1.7$ ) and 32 rock bursts which caused material and personnel losses. In recent years, 19 tremors have had energy $\mathrm{E} \geq 10^{8} \mathrm{~J}$, and two ones $\mathrm{E} \geq 10^{9} \mathrm{~J}$.

Between 2003 and 2014 hard coal production decreased from slightly over 100.0 million tons to 72.5 million tons [17]. In the analysed period, between $39 \%$ and over $50 \%$ of coal was produced in seams with rock burst hazard. Each year the number of rock bursts ranged between 1 and 5 . The rock bursts caused 125 serious and light accidents and 11 fatalities. As a consequence of the rock bursts a total of 520 metres of mine workings was destroyed, and approximately 3,600 metres of mine workings was damaged.

\section{Most common types of damage to powered support caused by rock bursts and decompression}

Within the framework of the project acronymed I2Mine titled "Innovative Technologies and Concepts for the Intelligent Deep Mine of the Future", realized by the Central Mining Institute, consequences of rock bursts and decompressions which occurred in $2003 \div 2012$ in all the coal mines of Kompania Węglowa S.A (KWSA), the biggest producer of hard coal in the European Union, were analysed. In the period, in KWSA's coal mines there were 18 
rock bursts and 14 decompression events. It was observed that $76 \%$ of the rock bursts and decompression events occurred during mining operations in longwall panels, $24 \%$ of them occurred while driving roadways. Consequences of rock bursts and decompression, which coincided with longwall operations, were mainly apparent in gateroads ( $49 \%$ of cases), moreover, in $31 \%$ of cases the damage was observed in longwalls themselves and in $20 \%$ in other adjacent mine workings.

Table 1 shows numerical values of the most important parameters characterising dynamic phenomena. Load coefficient $\mathrm{n}_{\mathrm{tz}}$, presented in Table 1 is calculated with the following empirical dependence [18]:

$$
n_{t z}=1+\frac{n_{z r}}{0,04 \cdot\left(\frac{H_{t}}{E_{t}}\right)^{0,7}+0,04 \cdot H_{t}+0,5}
$$

where:

$n_{z r}$ - coefficient considering location of analysed longwall and former mining operations,

$H_{t}$ - vertical distance of centre of layer being source of tremor from roof of working, $\mathrm{m}$,

$E_{t}-$ rock mass tremor energy, $\mathrm{MNm}$.

Table 1. Basic parameters of rock bursts and decompression occurring in Kompania Węglowa S.A.'s mines, 2003-2012 [8]

\begin{tabular}{|l|c|c|c|c|}
\hline \multirow{2}{*}{\multicolumn{1}{|c|}{ Parameter }} & \multicolumn{4}{c|}{ Phenomenon } \\
\cline { 2 - 5 } & \multicolumn{2}{|c|}{ Rock burst } & \multicolumn{2}{c|}{ Decompression } \\
\cline { 2 - 5 } & min & max & min & max \\
\hline Seismic energy of tremor, $(\mathrm{J})$ & $7.0 \mathrm{E}+05$ & $2.0 \mathrm{E}+08$ & $4.0 \mathrm{E}+04$ & $8.0 \mathrm{E}+07$ \\
\hline Peak particle velocity $P P V,(\mathrm{~m} / \mathrm{s})$ & 0.064 & 0.598 & $0.014^{*}$ & 0.353 \\
\hline Depth of mine working, $(\mathrm{m})$ & 630 & 1,085 & 545 & 1,130 \\
\hline Distance between tremor hypocentre and tremor effects, (m) & 24 & 567 & 37 & 572 \\
\hline $\begin{array}{l}\text { Vertical distance between tremor effects and tremor-prone } \\
\text { layer }\end{array}$ & 3 & 245 & 10 & 460 \\
\hline coefficient $n_{t z}$ & 1.10 & 1.51 & 1.05 & 1.53 \\
\hline
\end{tabular}

* PPV is estimated due to low accuracy to locate tremor hypocenter

Data presented in Table 1 show that workings and their support were damaged at seismic energy of tremor of $4.0 \mathrm{E}+04 \mathrm{~J}$ and relatively low load coefficient $n_{t z}=1.05$. A probable cause of such a situation in such cases was significantly high static load exerted on a support prior to a tremor, just before the dynamic phenomenon.

The calculated values of peak particle velocity $P P V$, being an empirical criterion of assessing stability of workings subjected to the influence of mine tremors, or the analysed 18 rock bursts and 14 decompression events were contained between $0.014 \mathrm{~m} / \mathrm{s}$ and 0.598 $\mathrm{m} / \mathrm{s}$. The values are confirmed by Mutke's research $[19,20]$. He determined that in the conditions of Polish hard coal mines workings lose stability when PPV is between 0.050 and $1.000 \mathrm{~m} / \mathrm{s}$.

The conducted analyses of dynamic phenomena in KWSA's mines enabled determination of the most common forms of damage to workings and support in longwalls, see Figure 1. 


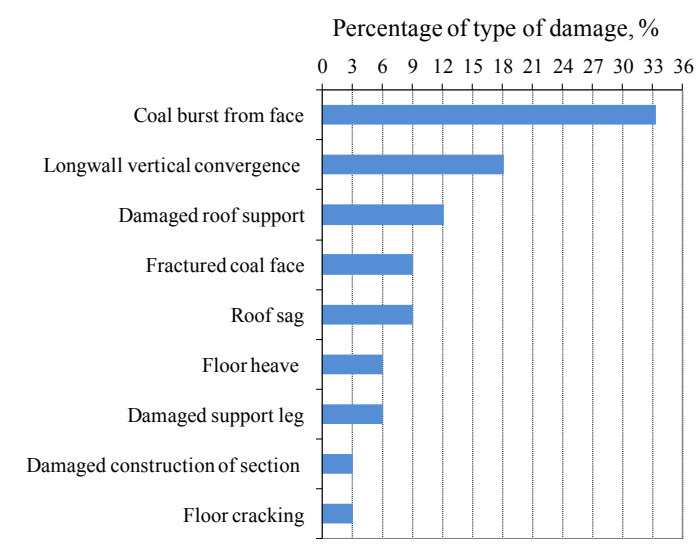

Fig. 1. Types of damage to longwalls and shield support caused by dynamic phenomena, $\%$

[8]

\section{Protecting powered support from consequences of rock bursts}

A lot of actions have been taken to limit consequences of damage to powered support or of stability loss in mine workings. It means preventing rock bursts with periodic destressing in zones where they concentrate or inducing rock mass tremors. The most often applied methods are: watering a seam, destressing drilling, loosening blasting, torpedo blasting, directed hydrofracturing of rocks, directed blasting fracturing, destressing a seam through mining adjacent seams [21-23]. Moreover, there are also conducted various types of underground tests [24-27] and laboratory tests [28] aimed at assessing influence of increased load induced by seismic phenomena on the support and stability of mine workings.

According to Polish legislation a powered roof support which is to work in longwalls driven in areas of rock mass tremors has to be flexible to absorb dynamic load. That is why, for many years, the Central Mining Institute has been conducting research into assessing flexibility of powered roof supports [28-30]. By "support flexibility", according to GIG's methodology, we mean the property of a powered roof support which enables it to absorb dynamic load safely, without exceeding values of its safety factor coefficient. The Central Mining Institute's method, assumes that hydraulic legs and flow rate of the hydraulic system, are the key elements making a given support flexible. The calculated minimal height of liquid column in the under piston space of a hydraulic leg (PT) and the determined flow rate of the system (together with a yielding valve) allows determination of the operation height range of a powered support, at which it is considered to be flexible under dynamic load (coefficient $n_{t z}$ ). In the calculations the value of maximum load on a leg and its nominal load are compared, in accordance with the following condition:

$$
F_{\max }<k \cdot F_{N}
$$

where:

$F_{\max }$ - value of maximum expected load on leg, considering rock mass tremor energy, $\mathrm{N}$

$F_{N}$ - leg nominal load, N.

$k$ - safety factor coefficient for hydraulic leg determined in laboratory (usually 1.5 or 2.0).

The value of maximum forecast load of a leg $\mathrm{F}_{\max }$ is determined analytically with the course of load versus time $f(t)$, basing on a model of one degree of freedom, and the equation $[28,30]$ : 


$$
f(t)=\frac{1}{\cos \alpha}\left\{F_{w}+F_{d}\left[1+k_{d} e^{-\delta \cdot t}-\sin (\omega t-\varphi)\right]\right\}
$$

where:

$F_{W}-$ leg setting load, N,

$F_{d}$-dynamic force of load, $F_{d}=n_{t z} \cdot F_{r}-F_{w}, \mathrm{~N}$,

$F_{r}-$ yield load, $\mathrm{N}$,

$n_{t z}-$ load coefficient,

$k_{d}$ - computational coefficient,

$\omega$ - angular velocity, $\mathrm{rad} / \mathrm{s}^{-1}$,

$\varphi$ - shift angle of the force with respect to input function, $\mathrm{rad}$,

$\alpha$-yaw angle of the leg from the normal to the support base,

$\delta$ - equivalent resulting from hydraulic valves and rock displacement resistance, $\mathrm{s}^{-1}$,

$t$ - time, s.

Flexibility of a section is also associated with flow rate of the hydraulic system, applied to limit pressure in the under piston space of a leg. It is important the configured hydraulic system securing the under piston space of a hydraulic leg did not limit flow $Q_{u}$ in selected yielding valves. The hydraulic system ought to have both optimised liquid streams geometry, and determined characteristics of flow of given elements in the whole system. Flow of liquid in the leg hydraulic system can be assessed in laboratory tests (Fig. 2) or by using numerical modeling based on ANSYS CFX software (Fig. 3) [31].
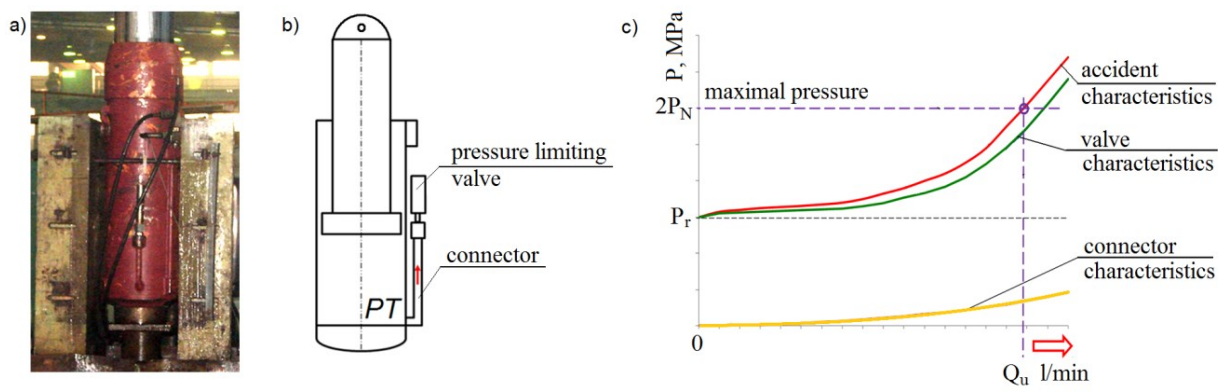

Fig. 2. Assessment of flow of liquid in hydraulic system of leg in laboratory tests: a - laboratory test site; $\mathrm{b}$ - hydraulic system of leg; $\mathrm{c}$ - flow characteristics; PT - under piston space; $\mathrm{P}_{\mathrm{r}}-$ leg yield pressure; $\mathrm{P}_{\mathrm{N}}-$ leg nominal pressure; $\mathrm{Q}_{\mathrm{u}}-$ minimal flow of system, [30]

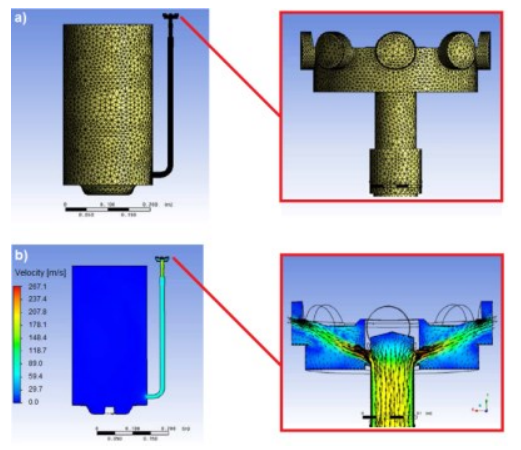

Fig. 3. Assessment of flow of liquid in leg hydraulic system performed with ANSYS CFX software: $\mathrm{a}$ - numerical model of system; $\mathrm{b}$ - results of flow velocity calculations [31]

Examples of assessment of powered support flexibility at height between 1.8 and $3.4 \mathrm{~m}$, applied in conditions where rock mass tremors occur is presented in Figure 4. The support is equipped with two-stage hydraulic legs with a check valve, with the first-stage cylinder 
diameter Ø $250 \mathrm{~mm}$. Single leg setting load is $1.227 \mathrm{MN}$, while yield load is $1.865 \mathrm{MN}$, which means the value of coefficient $n_{0}=0.66$ (ratio of setting pressure and yield pressure). Flexibility was assessed for two values of leg safety factor coefficient $k=1.5$ and $k=2.0$.

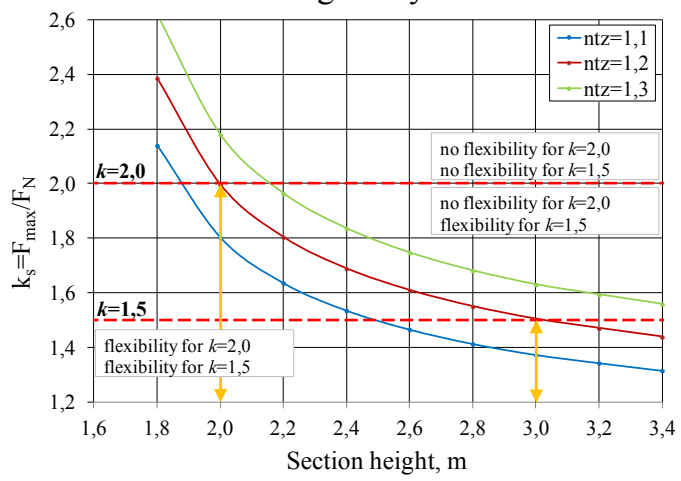

Fig. 4. Change in leg overload coefficient $k_{s}$ depending on operation height of shield and values of load coefficient $n_{t z}$ (assumptions: coefficient $n_{o}=0.66$, flow rate of yielding valve $Q=4001 / \mathrm{min}$ ) [32]

Minimum operation height of a powered support (Fig. 5), for which it meets the condition of flexibility, is determined by the point where the curve describing coefficient $k_{s}$ meets the value corresponding leg safety factor coefficient $k$, determined in laboratory tests $(k=1.5$ or $k=2.0)$. There are different possibilities (methods) to improve flexibility of a powered roof support, depending on the section operation height, and flow rate of yielding valves.

The presented method, formulated at GIG is commonly used in practice to assess or improve flexibility of powered roof support sections which are to work in Polish hard coal mines, in areas where rock mass tremors occur. The method is commonly used by both producers and users of powered supports.

\section{Summary}

Statistical data presented in the article and analyses concerning consequences of observed rock bursts and decompression events prove that they are phenomena posing a threat to personnel's safety, having a significant influence on the continuity of production. Recent years' practice showed that by applying a proper set of rules and safety measures it is possible to limit the above mentioned threats significantly. According to the GIG's method, to improve flexibility of a powered roof support, presented in the article, it is believed that sufficiently strong construction of the leg is significant. The construction ought to ensure its further operating when pressure in its under piston space increases to the double value of nominal pressure (safety factor coefficient $\mathrm{k}=2.0$ ). Then, the flow of liquid stream is optimized and a yielding valve of flow rate resulting from the forecast dynamic load is selected. Moreover, it is favourable, from the point of view of ability to absorb greater dynamic load by a powered roof support, to apply possibly the highest values of setting load (value of coefficient $\mathrm{n}_{0}$ increases). It is also possible to try to lower values of yield load. However, such a decision ought to be preceded with other analyses concerning proper co-operation between the powered roof support and the rock mass to stabilise the roof of a longwall.

Article presents a brief part of work carried out by the Central Mining Institute within the frame of research under the project: $\mathrm{I}^{2} \mathrm{M}$ Innovative Technologies and Concepts for the Intelligent Deep Mine of the Future. The project was implemented under The Seventh Framework Programme of the European Union. 


\section{References}

1. M. Bukowska, Forecasting of the liability of rock mass to rock-bumps by means of the method of indicatory geological-geomechanical assessment in conditions of Upper Silesian Coal Basin (in Polish). (Prace Naukowe GIG nr 866, Katowice, 2005)

2. J. Kozak, S. Gibowicz S., V. Rudajev, Stud. Geophys. Geod. 47, 641-650 (2003)

3. L. Driad-Lebeau, Int. J. of Coal Geo. 64, 66-78 (2005)

4. M. Profaska, Causes of damage to elements of powered roof supports in longwalls where rock bursts occurred (in Polish). Phd thesis, (Gliwice, 2001).

5. G. Bräuner, Gebirgsdruck und Gebirgsschläge. (Verlag Glückauf, Essen, 1991)

6. G. Mutke, Proceedings of 21st World Mining Congress 2008 - New Challenges and Vision for Mining. Underground Mine Environment, 89-97 (2008)

7. R. Durrheim, K. Riemer. Proceedings of International Mining History Congress, Johannesburg, 1-17 (2012).

8. S. Prusek, W. Masny. J. of Min. Sci., 51(1), 63-72 (2015)

9. J.R. Player, E. Villaescusa, and A.G. Thompson. Proceedings of Australian Mining Technology Conference, (2008).

10. J.L. Human, W.D. Ortlepp. Proceedings of 2nd Int. Seminar on Deep and High Stress Mining. SAIMM Symp. S37, 107 - 121 (2004)

11. S. Prusek, W. Masny. Proceedings of Aachen International Mining Symposia, 5th International Symposium - Mineral Resources and Mine Development, 295-308 (2015).

12. A. Kidybiński, Int. J. of Min. and Geo. Eng., 4, 91-109 (1986)

13. T.O. Hagan, A. Milev and S. Spottiswoode, J. of The S. Afric. Ins. of Min. and Met., 101(5), 217-222 (2001)

14. M. Płonka, Wiad. Gór. 12, 698-705 (2009)

15. G. Mutke, W. Masny, S. Prusek, Acta Geod. et Geom., 13 (4), 367-378 (2016).

16. S. Rajwa, W. Masny, S. Prusek, Proceedings of Aachen International Mining Symposia, $5^{\text {th }}$ International Symposium - High Performance Mining, 359-373 (2009)

17. R. Patyńska, Rock burst hazard: Yearly report on basic natural and technical hazards in hard coal mining in 2014(in Polish) (GIG, Katowice, 2015)

18. A. Biliński, Method of selecting support for conditions in mining panel (in Polish) (CMG Komag, Gliwice, 2005)

19. G. Mutke, Characteristics of vibrations caused by mine tremors in the vicinity seismic source concerning rock burst hazard assessment (in Polish) (Prace Naukowe GIG nr 872, Katowice, 2007)

20. G. Mutke, Proceedings of 21st World Mining Congress 2008 - New Challenges and Vision for Mining. Underground Mine Environment, 89-97 (2008)

21. J. Dubiński, W. Konopko, Rock bursts. Assessment. Forecast. Prevention (in Polish) (GIG, Katowice, 2000)

22. G. Brauner, Rockbursts in coal mines and their prevention. (Balkema, Rotterdam, 1994)

23. M. Junker, Gebirgsbeherrschung von Flözstrecken (Verlag Glückauf, Essen, 2006)

24. A. Kidybiński, A. Nierobisz, W. Masny, Proceedings of XII Międzynarodowa Konferencja Naukowo-Techniczna, 41-52 (2005)

25. L. Li, P. Hagan, S. Saydam, Proceedings of Rock Mechanics and Rock Engineering: structures on and in rock masses, EUROCK, DOI: 10.1201/b16955-183 (2014)

26. P. Małkowski, J. Polish Miner. Eng. Soc., 18 (2), 215-224 (2017)

27. M. Turek, Safety of steel arch support with roof bolts during rock mass tremors (in Polish) (GIG, Katowice, 2012)

28. K. Stoiński, Roof supports and rock mass tremor hazard (in Polish) (GIG, Katowice, 2000). 
29. S. Rajwa, W. Masny, S. Prusek, Proceedings of Aachen International Mining Symposia, $5^{\text {th }}$ International Symposium - High Performance Mining, 359-373.

30. K. Stoiński, S. Prusek, S. Rajwa, Proceedings of XXIII Międzynarodowa konferencja naukowo-techniczna, TEMAG, (2015)

31. L. Doległ o, J. Gil, K. Stoiński, Masz. Gór. 4, 9-18 (2009)

32. S. Prusek, Stability of longwall during hard coal mining operations with roof caving (in Polish) (GIG, Katowice, 2016) 